\title{
Cuban Underground Hip Hop: Black Thoughts, Black Revolution, Black Modernity by Tanya Saunders
}

\author{
Sarah Ohmer • City University of New York, Lehman College
}

University of Texas Press: Austin, TX, 2015. 368 pages. \$29.95, cloth. ISBN: 978-1-4773-0770-O

"A Queer of Color, Black Feminist Crucial Threat to Latinx Studies, Latin American Studies, Sociology and Hip Hop Studies"

$\mathrm{I}$ n Cuban Underground Hip Hop: Black Thoughts, Black Revolution, Black Modernity, Tanya Saunders presents the Cuban Underground Hip Hop Movement (СUннм) as "artivists" who create a nascent civil society in a totalitarian state. Thinking of subjectivity or identity formation with hip hop, sexuality, race, and latinidades, Saunders focuses on contemporary underground Cuban hip hop (separate from original Cuban Hip Hop). Theory-packed quotes are the product of participant observation from 1996 to 2006 during which Saunders attended concerts and interviewed artists and audience members. The artists and audience reveal a younger Cuban generation coming of age during the Special Period in Spanish interviews translated into English. The exodus of artists of синнм impacts hip hop in Havana and how other cities and provinces establish their own local hip hop movements.

The manuscript opens with a quote by a Cuban hip-hop producer: "Why am I a divisive person when I claim what my ancestors did? ... This [the musical, black Cuban musical] Cuban identity and contribution is often dismissed, hidden, and manipulated in this country [U.S.]," and the whole book confronts readers with what happens at the crux of Black and Cuban (and from Cuba!) (5). Cuban Underground Hip Hop effectively calls attention to processes that have erased part of what it means to be Cuban: the cultural process that recognizes African cultural legacies; and works towards enriching "Latino Studies" that whitewash Cuban identities and Cuban music.

Several claims in this book broaden the scope of AfroLatin American and Afro-Diaspora Studies. The introduction presents the impact of eurocentrism in Cuban nation-making and in Latinx Studies. Chapters 1 through 3 (Chapter 1: "Introduction," Chapter 2: "Historicizing Race, Cultural Politics, and Critical Music Cultures in Cuba" and Chapter 3: "La Revolución Dentro de la Revolución: Hip Hop, Cuba and Afro-Descendant Challenges to Coloniality") trace carefully how to rethink current notions of Western modernity while tracing and acknowledging Africans and their descendants in the formation of Cuban society and the West (and, I would add, in American Feminism). Throughout the book, one sees how and why the racism that continues today in the Americas is tied to $15^{\text {th }}-19^{\text {th }}$ centuries' cultural imaginaries. This, Saunders reminds us, comes back to the 'devious invention of modernity' established during Renaissance according to Mignolo. With Cuban Underground Hip Hop, sociologists, cultural studies theorists, and Latinx Studies and Latin Americanists, have a reference to recognize art as a part of politics; to engage cultural studies with sociological theories of social change; and to define art not as "prepolitical" or just affective release (16-17).

Artivism, Saunders explains, provides a contemporary, non-European aesthetic, and is not centered on the 'economy' (13). The синнм is defined as artivism that produces and contributes to Black thought, Black Modernity, and Black Revolution with an essential set of concepts. Chapter 5: "Never Has Anyone Spoken to You Like This': Examining the Lexicon of Cuban Underground Hip Hop Artivist Discourses" provides us with definitions to use in our studies (revolution; revolutionary; material poverty versus spiritual and conceptual poverty; etc.) (117).

The artivism coming out of СUннм is placed front and center with detailed analyses of lyrics and Mcs' experiential theories on hip-hop, poverty, gender, race and revolution, in Chapters 3-6. The Krudxs group, the main focus at the end of the book, pushes Cuban underground hip hop and Latinx Studies, Latin American Studies, Black Feminism, Queer and Gender and Women's Studies, Queer of Color Studies, Cultural Studies, Sociology, and Black Studies, with a Krudx 
perspective on activism and knowledge production and art. Learning from the Krudxs, one finds strategies to build communities in the face of multiple oppressions, including "invisible oppressions."

We sit with Saunders in that taxi watching her "pass as Cuban" and come to understand how one practices an intersectional semi-longitudinal sociological study (3). We can smell the sauce in the kitchen while four women discuss being mulatt@, trigueñ@, Black, and show their ID cards with racial nomenclatures to help Saunders understand whiteness, mulatt@ness, Blackness, and queeridad in cuнHм in Cuba (143-44).

“Whiteness, Mulat@nes, Blackness: Racial Identities and Politics within the Cuban Underground Hip Hop Movement" (Chapter 4) presents how different kinds of Blackness exist in синнм and how MCs engage their blackness as political engagement, with a crucial section on the importance of trying to understand the difficulty that mulatt@ness poses to Cuba's racial structure and to individuals in синнм, in Cuba, in Black modernity, Black thought, in queer of color studies: "It is an in-between space where others are always trying to tell him what his identity is, what his subject position is, and to which racial group he belongs. In his experience, he is never fully accepted anywhere... also suffered the traumas of slavery... and seeing those close to him dealing with racism." (146-47).

Cuban Underground Hip Hop offers a manual on how to study Cuba from the perspective of a sociologist who describes her challenges as an undergraduate, graduate, and faculty member while navigating the Cuban sociopolitical landscape. This is scholarly work in the Black, queer, American regional sense of the word, a hemispheric Black feminist and queer of color hip-hop studies work. Chapter 6 "I'm A Feminist, but I don't Hate Men" traces a multilayered study of Black feminism in CUнHм from 2000-2006, from Havana to Santiago de Cuba, including Omegas KILAY in Santiago de Cuba, NoNo12, Cristiane MC, among other MCS, with the the 2004 Hip Hop Symposium and Magia MC as central examples of increasingly diverse views and open dialogues on gender and sexuality among Black women in CUннм.

The Krudx are Black feminists from planet earth who break apart national borders and create revolutionary coalitions (153). "Kruda Knowledge, Kruda Discourse: Las Krudas CUBENSI, Transnational Black Feminism, and the Queer of Color Critique" (Chapter 7) wraps us with an epistemological climax in which Krudas cubensi (Cuban? Sí! ... Cuban? Yes!) create an anti-racist, anti-capitalist, non-heteronormative critique that intervenes into queer theory with a hemispheric, anticolonial queeridad.

The place, the race of the place, and the sexuality of artivists and scholars within this place, this place that has made political activism nonexistent, blackness nonexistent, and queerness abject, all the while Black Cuba is not understood in Latinx identity at the time when this book is being written... makes...

Cuban Underground Hip Hop.

Black Thoughts.

Black Revolution. Black Modernity.

A thriving threat of queeridad.

As I read/breathed/put the book down because it was too much to handle, I saw the Cuban streets and felt myself in Krudxs' apartment and Cuban hip-hop concerts.... I heard Lorde's anti-heterosexist reflections in Sister Outsider, the crucial contribution of José Esteban Muñoz on queer political performance of disidentification in American (in the regional sense of the word) Black feminist / queer of color studies. I read what felt as an equal to Global Designs/ Local Histories by Walter Mignolo, to Anibal Quijano's body of work on coloniality as a continuing condition and political state, and could note the resonance with Alice Walker's In Search of Our Mother's Gardens and Jacqui Alexander's Pedagogies of Crossing.

Diasporic identities are not bound to coloniality's geopolitical borders. Cuban Underground Hip Hop defines identity in Black America (in the regional sense) and Black Queer America and Hip Hop as subjectivities that are carried and reproduced within sound, no matter the geopolitical location (Weheliye 2005). I hear it, I read it but I also hear and feel it: identity in underground Hip Hop Studies (and beyond!!) is bound to sound and blackness/race/gender.

The Krudxs parallel the Combahee River Collective's work as they intervene in national and cultural spheres and discourses that do not address queer black feminist identities (socialism, anti-racism), and link their oppression to colonialism, slavery, imperialism. The raw, crude, hip hop artivists rhyme and provide us with language, art, experience, and other feminisms: elemental feminism (reminiscent of elements of hip hop), indigenous Cuban feminism, crude feminism, mujerista, and queeridad.

They show love is possible "We are demonstrating to the world that we have been together for almost ten years that it's possible that two women love each other and show it to everyone, not just in hip hop, but to all of Cuba that sees with your false heterosexual morals! We've been here for almost ten years, together, loving each other and inseperable, what to you want?! What's up?! So I think, as the community has said, this is an example. You understand me?" (282)

The Krudx work as artivists for love and life and "plant a seed for people to reflect on: embracing human diversity also means embracing sexual diversity" (283). They advocate for the right to love and to live: "as heterosexuality exists, homosexuality exists," and their lyrics move towards future discourses (283). Readers can think with Krudxs and Saunders about future discourses, where to go from here, the ability to 
imagine and the requirement for imagination/future within the present in order to survive and resist.

Hip-hop allows both Krudxs and the author to confront institutional blocks with transnational solidarity building blocks. Cuban Underground Hip Hop challenges the Eurocentric humanist Cuban culture, what and who counts as Cuban, and what and who counts as a "worthy" contributor to U.S. Latin Americanist discourse. With strategies to navigate complex heteronormative, racist, patriarchal, capitalist systems of U.S. Higher Education, U.S.-Cuba relations, Cuban racism and sexism, Cuban Underground Hip Hop complicates the Latino identities of Latino Studies, the Cuban identities in Cuban studies, the male cisgender hip hop identities in hip hop studies, the American identities in African American Studies and American Studies, and the lack of intersectional practices in Sociology.

Are we trying to keep secret that we are black or our Latin American nations are Black? Are we trying to keep secret that Latinx is also black? When we choose to (not) answer this, and to (not) focus on Black women and queer of color studies, to (not) redefine modernity, Cuban studies, Latin American Studies, then we contribute to the same conundrum that pretends that Western modernity is white, European, and somehow North American and not American (when the Americas are in the West, in the regional sense). For those of us who answer yes, with this book, we can work to let the secrets out.

\section{WORKS CITED}

Combahee River Collective (1978) 'The Combahee River Statement', in Hester Eisenstein (ed.) Capitalist Patriarchy and the Case for Socialist Feminism, Boston, MA: South End Press.

Lorde, Audre. Sister Outsider: Essays and Speeches. Trumansburg, NY: Crossing Press, 1984.

Quijano, Anibal, and Michael Ennis. "Coloniality of Power, Eurocentrism, and Latin America." Nepantla: Views from South. 1.3 (2000): 533-580. Print.

Migolo, Walter. The Darker Side of Western Modernity: Global Futures, Decolonial Options. Durham and London: Duke University Press, 2011. Print.
-- Local Histories/ Global Designs: Coloniality, Subaltern Knowledges, and Border Thinking. Princeton, NJ: Princeton U Press, 2012.

Muñoz, José Esteban. Disidentifications: Queers of Color and the Performance of Politics. Minneapolis, MN: University of Minnesota Press, 1999. Print.

Walker, Alice. In Search of Our Mothers' Gardens : Womanist Prose. San Diego, CA: Harcourt Brace Jovanovich, 1983. Print.

Weheliye, Alexander G. Phonographies: Grooves in Sonic AfroModernity. Durham, NC: Duke University Press, 2005. 